Tạp chí Khoa học và Công nghệ biển T10 (2010). Số 2. Tr 63 - 75

\title{
MÔ HÌNH QUẢN LÝ VÀ PHỤC HỔI THẢM CỎ BIỂN Ở HUYỆN NÚI THÀNH, TỈNH QUẢNG NAM
}

\author{
NGUYẼ̃N HŨ̃U ĐẠI
}

Viện Hải dương học

\begin{abstract}
Tóm tắt: 10 hecta thảm cỏ biển ở xã Tam Giang, huyện Núi Thành, tỉnh Quảng Nam đã được chọn và được UBND tỉnh Quảng Nam ký quyết định số 1938/QD-UBND ngày 09 tháng 6 năm 2008 giao cho dư án "Quản lý tổng hợp đới bò̀ Quảng Nam" để thưc hiện mô hình trình diễn phuc hồi hệ sinh thái cỏ biển. Đây là vùng trung tâm phân bố của cỏ biển ỏ đầm An Hòa, Núi Thành với sư uu thế của loài cỏ Luoon Zostera japonica, độ bao phủ có noi đạt 25-50\%, nhung hiện nay đang bị suy giảm nhanh do các hoạt động khai thác hải sản có tính hủy diệt. Mô hình trình diễn được thực hiện nhờ sụ hỗ trợ của chính quyền địa phuoong, nhóm hạt nhân gồm 4 người và cộng đồng cu dân địa phuoong. Cỏ Luơn đã được di trồng phuc hồi theo phuoong pháp PU (bưng luôn trầm tích và cỏ). Kết quả kiểm tra buớc đầu sau 6 tuần di trồng cho thấy mật độ thân đứng cỏ Luơn tăng $13 \%$. Việc vận hành mô hình đuợc đề nghị trên cơ sở gắn kết lọi ích của việc khai thác hợp lý và bền vũng nguồn lợi trong hệ sinh thái cỏ biển với việc quản lý và bảo vệ chúng.
\end{abstract}

\section{MỞ ĐÀ̀U}

Các kết quả nghiên cứu các thảm cỏ biển ở Việt Nam đã cho thấy riêng ở vùng ven biển và các đảo ven bờ các tỉnh phía Nam cỏ biển phân bố thành các vùng rộng lớn hàng trăm hecta nhất là ở các tỉnh Quảng Nam, Phú Yên, Khánh Hòa, Ninh Thuận, Bình Thuận, Vũng Tàu Côn Đảo, Phú Quốc ...Các thảm cỏ biển này đang đảm nhiệm vai trò quan trọng đối với môi trường và sinh vật, là nơi cư trú sinh vật đa dạng, nơi nuôi dưỡng ấu thể của nhiều loài sinh vật và cung cấp giống cho các vùng biển lân cận (Nguyễn Hữu Đại \& CS 1999, 2000). Tuy nhiên đây là nơi đang xảy ra mạnh mẽ các hoạt động nuôi trồng và khai thác quá mức hoặc các cách đánh bắt có tính hủy diệt của cư dân ven biển. Các hoạt động này đã làm cho các thảm cỏ biển bị suy giảm mạnh hoặc mất đi. Chỉ riêng ở vùng biển Khánh Hòa trong 5 năm qua đã có khoảng $30 \%$ diện tích các thảm cỏ biển đã bị mất đi hoặc suy giảm nghiêm trọng (Nguyễn Hữu Đại \& CS 2002). Sự mất đi của các thảm cỏ biển làm mất đi nơi cư trú sinh vật, đồng thời dẫn đến suy giảm chất lượng môi trường cũng như tính đa dạng sinh học và nguồn lợi. 
Ở tỉnh Quảng Nam, các kết quả khảo sát của chúng tôi đã cho thấy các thảm cỏ biển chiếm gần hết vùng biển nông ven bờ vùng An Hòa, Núi Thành với sự ưu thế của 3 loài cỏ biển: cỏ Lươn Zostera japonica, cỏ Hẹ Halodule uninervis, và cỏ Xoan Halophila ovalis. Tuy nhiên, các thảm cỏ này đang bị suy giảm nhanh, là hệ quả của các hoạt động khai thác không hợp lý. Xiết điện cùng với nghề cào đáy và đào bắt hải sản đã làm suy giảm nghiêm trọng hệ sinh thái cỏ biển, sinh vật non bị bắt hoặc chết, còn cỏ biển bị cào, nhổ khỏi trầm tích và trôi dạt khắp nơi. Việc quản lý và bảo vệ chúng là rất cấp thiết trước khi thảm cỏ này bị mất, và để phục hồi là rất tốn kém và khó khăn.

Tham khảo các tài liệu tính toán về việc phục hồi các thảm cỏ biển ở vùng ôn đới (ví dụ với cỏ Lươn Zostera), phải mất từ 9.000 đến 46.000 USD/hecta bằng cách dùng phương pháp lấy luôn trầm tích và cỏ. Nếu dùng phương pháp lấy thân ngầm và thân đứng, phí tổn từ 11.000 đến $74.000 \mathrm{USD} /$ hecta (Spurgeon, 1998). Báo cáo của chương trình hành động Quốc gia về đa dạng sinh học của Anh Quốc cũng đã cho biết giá cả để phục hồi cỏ biển ở đây là 8.600 USD/hecta và khoảng 1000 hecta đã được di trồng phục hồi (Spurgeon 1998). Do vậy việc quản lý và bảo vệ phải được ưu tiên thực hiện, nếu không, khi các thảm cỏ biển bị mất đi thì việc phục hồi rất tốn kém và khó khăn.

\section{TÀI LIỆU VÀ PHƯƠNG PHÁP NGHIÊN CÚU}

Bài viết sử dụng các số liệu của mô hình quản lý và phục hồi cỏ biển xã Tam Giang, Núi Thành, thuộc dự án Quản lý Tổng hợp đới bờ Quảng Nam, thực hiện từ năm 2006 đến 2008.

Khu vực được chọn đề tiến hành mô hình là vùng trung tâm phân bố của cỏ biển ở Xã Tam Giang, đầm An Hòa, nơi mà hệ sinh thái cỏ biển có tính đa dạng sinh học cao.

Tiến hành đánh giá cấu trúc thảm cỏ biển trước khi thực hiện mô hình. Sử dụng phương pháp mặt cắt, thực hiện theo Quy phạm điều tra biển, phần thực vật biển do Ủy ban Khoa học và Kỹ thuật Nhà nước ban hành (1981) và các phương pháp trong "Hướng dẫn điều tra nguồn lợi biển nhiệt đới” của English, Wilkinson \& Baker (1994) và "Các phương pháp nghiên cứu về cỏ biển" của Philips \& McRoy (1990). Theo đó các mặt cắt được thực hiện một cách ngẫu nhiên sao cho chúng có tính đại diện cho hiện trạng cỏ biển vùng khảo sát. Trên mỗi mặt cắt có 3 trạm thu mẫu để tiến hành các khảo sát về thành phần loài, mật độ, độ bao phủ, sinh lượng, thường là một trạm ở vùng phân bố trên, một ở vùng phân bố giữa và một ở đai phân bố dưới của khu vực phân bố thảm cỏ biển. Khung sinh lượng có diện tích $0,25 \mathrm{~m}^{2}$, được chia thành 25 ô nhỏ $1 \mathrm{dm}^{2}$. Tại các khung này độ bao phủ của các loài cỏ biển được tính trong từng ô nhỏ và sau đó tính chung cho khung $0,25 \mathrm{~m}$ 2 theo phương pháp của Saito \& Abe (1970). 
Kỹ thuật trồng phục hồi cỏ biển được áp dụng từ các kết quả nghiên cứu trong phòng thí nghiệm (N. H. Đại, 2005). Loài cỏ biển ưu thế và được di trồng phục hồi ở đây là cỏ Lươn (Zostera japonica) là loài ưu thế tại địa phương, có kích thước nhỏ và sinh sản chủ yếu bằng hình thức sinh sản dinh dưỡng. Áp dụng đặc điểm này, sử dụng kỹ thuật lấy giống cỏ cùng với phần trầm tích (PU - Planting Unit). Các khung thép hình trụ có tiết diện $14 \mathrm{~cm}$ được sử dụng làm dụng cụ để lấy các bụi cỏ biển. Nguồn giống được thu thập từ các vùng lân cận, nơi cỏ biển có tình trạng sức khỏe tốt, độ bao phủ trung bình từ 75 - 100\%, mức độ cho phép lấy $20 \%$ (N. H. Đại, 2005). Mỗi bụi cỏ giống có mật độ từ 200 - 250 thân đứng. Các bụi cỏ giống này sau đó được trồng trong các hố có kích thước bằng với nó, hàng cách hàng $50 \mathrm{~cm}$. Kỹ thuật di trồng được tập huấn cho nhóm hạt nhân thực hiện mô hình và cộng đồng dân cư địa phương. Để kiểm tra sự thích nghi phát triển của cỏ biển di trồng đã bố trí 3 lô thí nghiệm, mỗi lô gồm 10 bụi cỏ có mật độ thân đứng ban đầu được kiểm soát như nhau. Sau 6 tuần di trồng mật độ cỏ ở các lô thí nghiệm được đánh giá lại.

\section{KẾT QUẢ}

\section{Chọn lựa địa điểm triển khai mô hình phục hồi}

\section{Các tiêu chí chọn địa điểm}

Việc lựa chọn điểm trình diễn phục hồi được thực hiện theo các tiêu chí như sau:

- Có tính đa dạng sinh học cao, là vùng phân bố quan trọng của cỏ biển.

- Có vai trò quan trọng đối với môi trường và nguồn lợi sinh vật của một khu vực

- Đang bị suy giảm

- Được sự ủng hộ của chính quyền địa phương và sự đồng thuận của cộng đồng.

\section{Khu vực thử nghiệm phục hồi}

Áp dụng các tiêu chí trên, vùng được chọn nằm ở thôn 1,2 xã Tam Giang, diện tích triển khai khoảng 10 ha có hình chữ nhật (hình 1 ). Khu vực trình diễn quản lý và phục hồi cỏ biển được thực hiện do quyết định số 1938/QĐ-UBND ngày 09 tháng 6 năm 2008 của UBND tỉnh Quảng Nam. Vị trí tọa độ tại 4 điểm góc là:

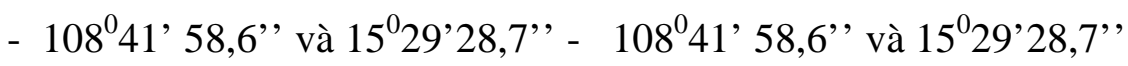

$$
\begin{aligned}
& \text { - } 108^{0} 41^{\prime} 30^{\prime \prime} \text { và } 15^{0} 29^{\prime} 57^{\prime} \text { ' - } 108^{0} 39^{\prime} 41,8^{\prime \prime} \text { và } 15^{0} 28^{\prime} 07,5^{\prime}, \\
& \text { - } 108^{0} 41^{\prime} 55,8^{\prime \prime} \text { và } 15^{0} 30^{\prime} 13^{\prime} \text { ' - } 108^{0} 39^{\prime} 37,2 \text { ' và } 15^{0} 28^{\prime} 57,2 \text { ', } \\
& \text { - } 108^{0} 41^{\prime} 19^{\prime \prime} \text { và } 15^{0} 29^{\prime} 47^{\prime}, \text { - } 108^{0} 39^{\prime} 19,8^{\prime \prime} \text { 'và } 15^{0} 28^{\prime} 06,3^{\prime},
\end{aligned}
$$




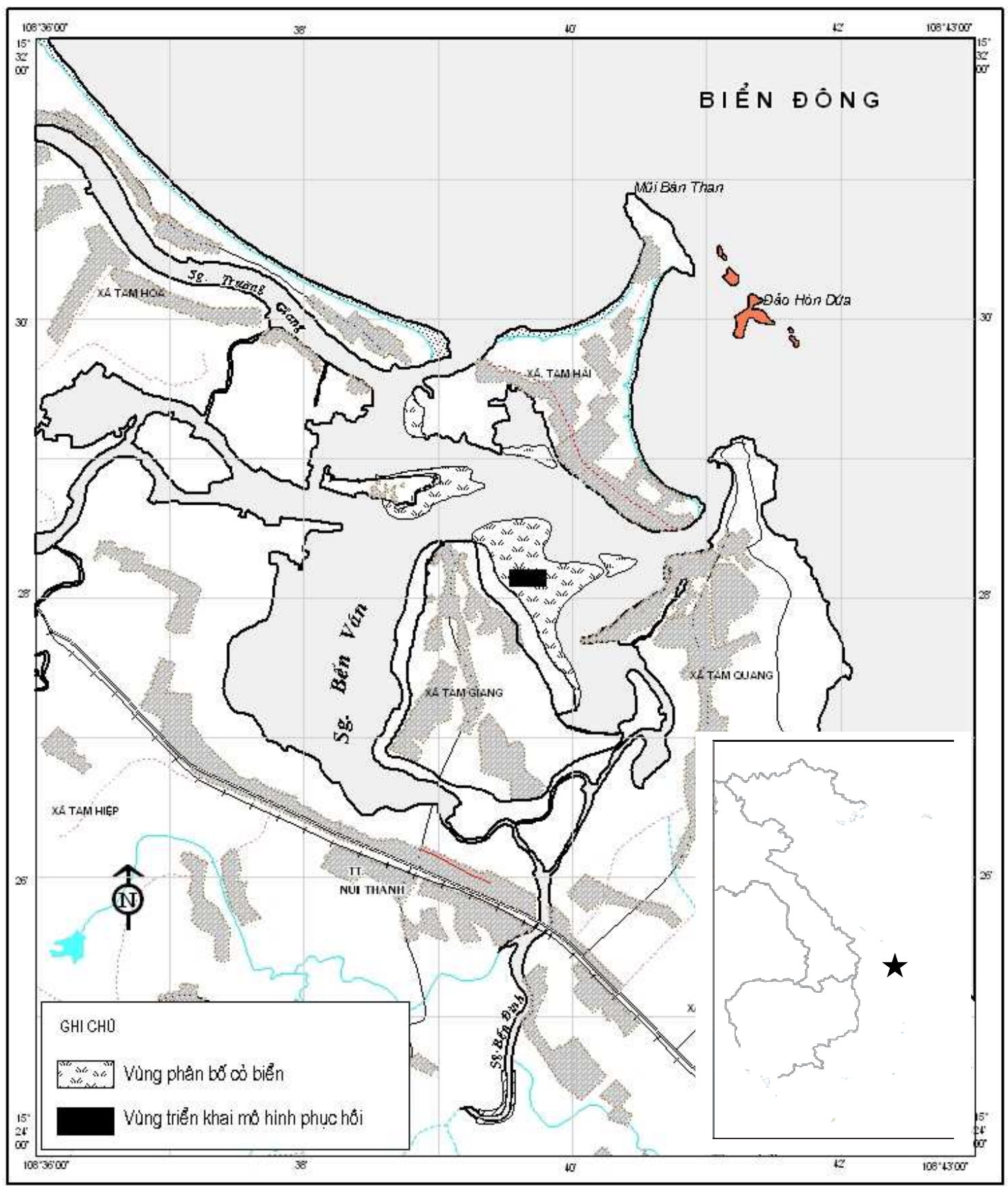

Hình 1: Khu vực triển khai mô hình phục hồi cỏ biển (xã Tam Giang, Núi Thành)

Khu vực này là vùng phân bố tự nhiên của cỏ biển, trải dài theo ven bờ, dài $500 \mathrm{~m}$, rộng 200 mét. Đây là vùng phân bố quan trọng của cỏ biển ở xã Tam Giang. Thảm cỏ này hiện nay đang bị suy giảm khoảng $30 \%$ do các hình thức đánh bắt và khai thác có tính hủy 
diệt, nhiều khoảng trống do cỏ bị chết. Trong khu vực này, tiến hành di trồng phục hồi khoảng 1 hecta, tập trung vào vùng bị suy giảm mạnh hoặc bị chết, phần còn lại được khoanh vùng quản lý, chăm sóc và bảo vệ.

Chất đáy chủ yếu trong vùng này là cát pha bùn, có lẫn nhiều xác vỏ sò ốc, nền đáy bằng phẳng, vào thời gian triều thấp nhất, thường ngập nước từ 0,2 đến 1 mét. Độ mặn đo được từ tháng 10-12 (mùa mưa) nằm trong khoảng 15 -20\%o, thích hợp cho việc phát triển của cỏ biển. Những khi mưa lớn kéo dài, độ mặn có thể thấp hơn nhưng thời gian không lâu.

Do tính đa dạng sinh học cao và nguồn lợi phong phú, đây là khu vực thường xuyên được ngư dân khai thác bằng đủ mọi hình thức từ cách lượm nhặt thô sơ cho đến xiết điện, lưới cào hoặc các cách khai thác có tính phá hủy nơi cư trú như đào xới bắt trùng biển hay ngao sò. Tất cả các hoạt động kể trên đều gây suy giảm hoặc mất các thảm cỏ. Chúng phân bố thưa, da beo, nhiều khoảng trống. Nhiều người dân cho biết trước đây mật độ cỏ rất dày, chiều cao lá thường dài hơn $20 \mathrm{~cm}$.

\section{Hiện trạng các thảm cỏ biển ở vùng Núi Thành, Quảng Nam}

Núi Thành là khu vực phân bố quan trọng của cỏ biển ở phía nam của tỉnh Quảng Nam, diện tích phân bố khoảng 200 hecta, chủ yếu tập trung ở đầm An Hoà, khu vực vùng triều ven biển thuộc địa bàn các xã Tam Giang, Tam Hải, Tam Quang, (huyện Núi Thành). Các thảm cỏ biển này bao phủ hầu hết các vùng nước nông, các cồn gò, từ mực triều thấp đến sâu 0,5-2 mét, ngoại trừ các lạch sâu.

3 loài cỏ biển thưởng gặp là

- Cỏ Lươn Zostera japonica

- Cỏ Xoan tròn Halophila ovalis

- Cỏ Hẹ Halodule uninervis

Riêng vùng Bàn Thang (xã Tam Hải, Núi Thành) thảm cỏ biển còn có thêm các loài:

- Cỏ Vích Thalassia hemprichii

- Cỏ Xoan lá dài Halophila decipiens phân bố từ độ sâu 3 - 4 mét trở xuống.

Thảm cỏ biển trong đầm An Hòa tương đối khá đồng nhất. Loài ưu thế nhất là cỏ Lươn phân bố khắp mọi nơi, kể cả trong các ao đìa nuôi tôm. Chúng có chiều cao thân đứng từ $10-20 \mathrm{~cm}$. Nhiều ngư dân cho biết trước đây chúng cao đến $30-40 \mathrm{~cm}$ (giống với thảm cỏ ở Cửa Đại, Hội An) nhưng nay cằn cổi và ngắn hơn. Loài cỏ Xoan lá tròn mọc xen kẻ với loài trên và phát triển ưu thế ở vùng dưới triều luôn ngập nước. Ngoài ra trong các ao đìa bỏ hoang còn gặp cỏ Kim Ruppia maritima. 
Do độ mặn trong đầm An Hòa tương đối ít thay đổi trong mùa mưa hoặc chỉ bị ngọt hóa trong thời gian ngắn khi xảy ra lũ lớn cho nên cấu trúc của các thảm cỏ biển ít thay đổi theo mùa. Sau đây là kết quả các chuyến khảo sát cấu trúc các thảm cỏ quan trọng trong đầm An Hòa vào tháng 9/2007 (cuối mủa khô) và tháng 01/2008 (cuối mùa mưa).

Bảng 1: Cấu trúc của các thảm cỏ biển ở một số vùng phân bố tập trung ở đầm An Hòa, Núi Thành tháng 9/2007 và tháng 01/2008

\begin{tabular}{|c|c|c|c|c|c|c|c|c|}
\hline \multirow{2}{*}{ Địa điểm } & \multirow{2}{*}{ Tọa độ } & \multirow{2}{*}{$\begin{array}{c}\text { Tên loài } \\
\text { cỏ }\end{array}$} & \multicolumn{2}{|c|}{$\begin{array}{l}\text { Mật độ } \\
\text { (cây/m²) }\end{array}$} & \multicolumn{2}{|c|}{ Độ bao phủ (\%) } & \multicolumn{2}{|c|}{$\begin{array}{c}\text { Sinh lượng } \\
\left(\mathrm{g} \text { khô//m } \mathbf{m}^{2}\right)\end{array}$} \\
\hline & & & $\mathbf{9 / 0 7}$ & $01 / 08$ & 9/07 & 01/08 & 9/07 & $\begin{array}{c}01 / 0 \\
8\end{array}$ \\
\hline $\begin{array}{l}\text { Long Thạnh } \\
\text { Đông } \\
\text { xã Tam Hải }\end{array}$ & $\begin{array}{c}15^{0} 28^{\prime} 308 \\
108^{0} 40^{\prime} 475\end{array}$ & $\begin{array}{c}\text { Cỏ Hẹ } \\
\text { Cỏ Xoan } \\
\text { tròn }\end{array}$ & $\begin{array}{l}980 \\
230\end{array}$ & $\begin{array}{l}820 \\
300\end{array}$ & $\begin{array}{l}<6,25 \\
<6,25\end{array}$ & $\begin{array}{l}<6,25 \\
<6,25\end{array}$ & $\begin{array}{l}76 \\
58\end{array}$ & $\begin{array}{l}46 \\
22\end{array}$ \\
\hline $\begin{array}{c}\text { Cồn Si (1) } \\
\text { Xã Tam } \\
\text { Giang }\end{array}$ & $\begin{array}{c}15^{0} 28^{\prime} 935 \\
108^{0} 39^{\prime} 248\end{array}$ & $\begin{array}{l}\text { Cỏ Hẹ } \\
\text { Cỏ Lươn }\end{array}$ & $\begin{array}{c}11.20 \\
0 \\
820\end{array}$ & $\begin{array}{l}2.600 \\
7.200\end{array}$ & $\begin{array}{l}25-50 \\
<6,25\end{array}$ & $\begin{array}{c}6,25- \\
12,5 \\
12,5-25\end{array}$ & $\begin{array}{c}248 \\
84\end{array}$ & $\begin{array}{c}78 \\
104\end{array}$ \\
\hline $\begin{array}{c}\text { Cồn Si (2) } \\
\text { Xã Tam } \\
\text { Giang }\end{array}$ & $\begin{array}{c}15^{0} 28^{\prime} 879 \\
108^{0} 38^{\prime} 962\end{array}$ & $\begin{array}{l}\text { Cỏ Lươn } \\
\text { Cỏ Xoan } \\
\text { tròn }\end{array}$ & $\begin{array}{l}9800 \\
1200\end{array}$ & $\begin{array}{c}8.800 \\
420\end{array}$ & $\begin{array}{c}25-50 \\
6,25- \\
12,5\end{array}$ & $\begin{array}{c}25-50 \\
6,25- \\
12,5\end{array}$ & $\begin{array}{c}201 \\
76\end{array}$ & $\begin{array}{c}191 \\
26\end{array}$ \\
\hline $\begin{array}{c}\text { Gần cảng, } \\
\text { Tam Giang } 1\end{array}$ & $\begin{array}{c}15^{0} 28^{\prime} 558 \\
108^{0} 39^{\prime} 402\end{array}$ & Cỏ Lươn & $\begin{array}{c}12.50 \\
0\end{array}$ & 11.000 & $25-50$ & $25-50$ & 287 & 221 \\
\hline Tam Giang 2 & $\begin{array}{c}15^{0} 28^{\prime} 618 \\
108^{0} 39^{\prime} 740\end{array}$ & $\begin{array}{c}\text { Cỏ Lươn } \\
\text { Cỏ Hẹ }\end{array}$ & $\begin{array}{c}11.60 \\
0 \\
6200\end{array}$ & $\begin{array}{c}8000 \\
600\end{array}$ & $\begin{array}{c}25-50 \\
6,25- \\
12,5\end{array}$ & $\begin{array}{l}25-50 \\
<6,25\end{array}$ & $\begin{array}{c}262 \\
98\end{array}$ & $\begin{array}{c}170 \\
38\end{array}$ \\
\hline Tam Giang 3 & $\begin{array}{c}15^{0} 28^{\prime} 274 \\
108^{0} 39^{\prime} 607\end{array}$ & $\begin{array}{l}\text { Cỏ Lươn } \\
\text { Cỏ Xoan }\end{array}$ & $\begin{array}{l}7800 \\
5800\end{array}$ & $\begin{array}{l}7600 \\
5200\end{array}$ & $\begin{array}{c}12,5-25 \\
6,25- \\
12,5\end{array}$ & $\begin{array}{c}12,5-25 \\
6,25- \\
12,5\end{array}$ & $\begin{array}{l}88 \\
64\end{array}$ & $\begin{array}{l}86 \\
60\end{array}$ \\
\hline $\begin{array}{c}\text { Thôn } 2 \text { Tam } \\
\text { Giang }\end{array}$ & $\begin{array}{c}15^{0} 28^{\prime} 009 \\
108^{0} 39^{\prime} 810\end{array}$ & Cỏ Lươn & $\begin{array}{c}13.20 \\
0\end{array}$ & 12.200 & $25-50$ & $25-50$ & 284 & 244 \\
\hline $\begin{array}{c}\text { Thôn } 3 \\
\text { Tam Giang }\end{array}$ & $\begin{array}{c}15^{0} 27^{\prime} 863 \\
108^{0} 39^{\prime} 790\end{array}$ & $\begin{array}{l}\text { Cỏ Lươn } \\
\text { Cỏ Xoan } \\
\text { tròn }\end{array}$ & $\begin{array}{c}12.40 \\
0 \\
2.800\end{array}$ & $\begin{array}{l}11.000 \\
2.200\end{array}$ & $\begin{array}{c}25-50 \\
6,25- \\
12,5\end{array}$ & $\begin{array}{c}25-50 \\
6,25- \\
12,5\end{array}$ & $\begin{array}{c}272 \\
42\end{array}$ & $\begin{array}{c}232 \\
35\end{array}$ \\
\hline
\end{tabular}


Kết quả trên cho thấy vào mùa nắng $(9 / 2007)$ và vừa hết mùa mưa $(01 / 2008)$ cấu trúc của các thảm cỏ biển ở Núi Thành ít thay đổi. Các thảm cỏ biển ở đây vẫn có tình trạng tốt vào cuối mùa mưa. Vào lúc này mật độ cỏ biển có giảm và chiều cao của cỏ ngắn hơn (trung bình khoảng $10 \mathrm{~cm}$ ).

\section{3. Đánh giá cấu trúc thảm cỏ biển khu vực triển khai mô hình}

Bảng 2: Cấu trúc thảm cỏ biển khu vực triển khai mô hình (tháng 4/2008)

\begin{tabular}{|c|c|c|c|c|c|}
\hline $\begin{array}{l}\text { Mặt } \\
\text { cắt }\end{array}$ & $\begin{array}{c}\text { Khung sinh } \\
\text { lượng }\end{array}$ & Tên loài cỏ & $\begin{array}{l}\text { Mật độ } \\
\text { (cây/m²) }\end{array}$ & $\begin{array}{c}\text { Độ bao } \\
\text { phủ (\%) }\end{array}$ & $\begin{array}{c}\text { Sinh lượng } \\
(\mathrm{g} \text { khô/m²) }\end{array}$ \\
\hline \multirow{4}{*}{1} & \multirow{2}{*}{1.1} & Cỏ Lươn & 12.500 & $25-50$ & 231,16 \\
\hline & & Cỏ Hẹ & 1.700 & $<6,25$ & 32,32 \\
\hline & 1.2 & Cỏ Lươn & 14.200 & $25-50$ & 288,51 \\
\hline & 1.3 & Cỏ Hẹ & 3.200 & $<6,25$ & 37,30 \\
\hline \multirow{5}{*}{2} & & Cỏ Lươn & 11.600 & $25-50$ & 262,20 \\
\hline & 2.1 & Cỏ Hẹ & 6.200 & $6,25-12,5$ & 98,30 \\
\hline & \multirow{2}{*}{2.2} & Cỏ Lươn & 13.400 & $25-50$ & 314,25 \\
\hline & & Cỏ Xoan tròn & 700 & $<6,25$ & 27,10 \\
\hline & 2.3 & 0 & & & \\
\hline \multirow{5}{*}{3} & \multirow{2}{*}{3.1} & Cỏ Lươn & 10.300 & $25-50$ & 223,70 \\
\hline & & Cỏ Hẹ & 5420 & $6,25-12,5$ & 36,38 \\
\hline & \multirow{2}{*}{3.2} & Cỏ Lươn & 12.600 & $25-50$ & 334,50 \\
\hline & & Cỏ Xoan tròn & 4620 & $6,25-12,5$ & 40,10 \\
\hline & 3.3 & Cỏ Xoan & 1200 & $<6,25$ & 22,18 \\
\hline \multirow{5}{*}{4} & \multirow{2}{*}{4.1} & Cỏ Lươn & 11.840 & $25-50$ & 233,50 \\
\hline & & Cỏ Hẹ & 4800 & $6,25-12,5$ & 36,30 \\
\hline & \multirow{2}{*}{4.2} & Cỏ Lươn & 13.260 & $25-50$ & 272,18 \\
\hline & & Cỏ Xoan tròn & 2200 & $<6,25$ & 18,21 \\
\hline & 4.3 & 0 & & & \\
\hline \multirow{4}{*}{5} & 5.1 & Cỏ Lươn & 12.800 & $25-50$ & 229,15 \\
\hline & \multirow{2}{*}{5.2} & Cỏ Lươn & 9700 & $12,5-25$ & 172,40 \\
\hline & & Cỏ Xoan tròn & 3320 & $<6,25$ & 32,10 \\
\hline & 5.3 & 0 & & & \\
\hline
\end{tabular}


Khảo sát đánh giá hiện trạng cấu trúc thảm cỏ biển trước khi tiến hành thực hiện mô hình. 5 mặt cắt ngang qua vùng 10 hecta của mô hình phục hồi. Trên mỗi mặt cắt lấy ngẫu nhiên 3 khung sinh lượng theo thứ tự 1, 2, 3 từ trong bờ ra vùng luôn ngập nước.

Cấu trúc thảm cỏ biển qua 5 mặt cắt ngang qua khu vực 10 hecta quản lý cỏ biển theo thứ tự từ phía Bắc xuống phía Nam được thể hiện qua bảng sau:

Kết quả cho thấy từ vùng triều trung bình đến vùng triều thấp, độ bao phủ cỏ biển tương đối cao, có nơi đạt từ $25-50 \%$. Nhưng từ vùng triều thấp đến vùng ngập nước 0,5 1 mét khi triều thấp nhất cỏ biển bị mất hoặc suy giảm nhiều. Nguyên nhân là do ở vùng luôn ngập nước, các hoạt động đánh bắt bằng lưới cào, xiết điện làm chết cỏ. Đánh giá chung diện tích cỏ biển bị mất đi hay suy giảm trung bình trong khu vực 10 hecta quản lý này là khoảng $30 \%$. Việc đánh giá này là cần thiết để kiểm tra tác động của việc quản lý bảo vệ và di trồng phục hồi đối với thảm cỏ biển.

\section{Di trồng phục hồi}

Trong 10 hecta khu vực quản lý, 1 hecta ở vùng trung tâm được chọn để tiến hành triển khai mô hình di trồng phục hồi. Khu vực này được rào lưới xung quanh.

Nhóm hạt nhân và cộng đồng dân cư địa phương đã được tập huấn kỹ thuật di trồng. Để thuận tiện và có hiệu quả, công việc được tiến hành vào thời điểm thủy triều xuống thấp, thường là buổi chiều. Trong quá trình thực hiện (tháng 9 - 10/2008), cư dân trong vùng rất quan tâm và họ mong muốn được phép nhân rộng mô hình này ra xung quanh.

Bảng 3: Phát triển mật độ thân đứng của cỏ Lươn di trồng ở 3 lô thí nghiệm

\begin{tabular}{|c|c|c|c|c|c|c|}
\hline \multirow{2}{*}{$\begin{array}{c}\text { Tên loài } \\
\text { cỏ }\end{array}$} & \multicolumn{3}{|c|}{$\begin{array}{l}\text { 18/10/08 (bắt đầu di trồng, mật } \\
\text { độ ban đầu giống nhau ở các lô } \\
\text { thí nghiệm) }\end{array}$} & \multicolumn{3}{|c|}{$\begin{array}{l}\text { Mật độ trung bình thân đứng của các } \\
\text { bụi cỏ còn sống sót }(03 / 12 / 08)\end{array}$} \\
\hline & $\begin{array}{l}\text { Thí nghiệm } \\
\text { (TN) } 1 \\
\text { (10 bụi) }\end{array}$ & $\begin{array}{c}\text { TN } 2 \\
\text { (10 bụi) }\end{array}$ & $\begin{array}{c}\text { TN } 3 \\
\text { (10 bụi) }\end{array}$ & TN 1 & TN 2 & TN 3 \\
\hline $\begin{array}{l}\text { Cỏ Lươn } \\
\text { Nhật } \\
\text { Zostera } \\
\text { japonica }\end{array}$ & $\begin{array}{l}200 \text { thân } \\
\text { đứng/bụi }\end{array}$ & $\begin{array}{l}200 \text { thân } \\
\text { đứng/bụi }\end{array}$ & $\begin{array}{l}200 \text { thân } \\
\text { đứng/bụi }\end{array}$ & $\begin{array}{c}\begin{array}{c}227,14 \\
\pm 36,83\end{array} \\
\text { (Số bụi cỏ } \\
\text { còn sống : 7) }\end{array}$ & $\begin{array}{c}231,66 \\
\pm 24,83 \\
\text { (Số bụi cỏ } \\
\text { còn } \\
\text { sống :6) }\end{array}$ & $\begin{array}{c}224,75 \\
\pm 35,57 \\
\text { Số bụi cỏ } \\
\text { còn sống : } 8 \text { ) }\end{array}$ \\
\hline
\end{tabular}


Để kiểm tra và đánh giá sự thích nghi, tồn tại, cũng như sự phát triển của cỏ biển di trồng có nhiều phương pháp: tăng trưởng chiều dài lá, năng suất lá, mật độ, độ bao phủ. Việc chọn lựa phương pháp tùy thuộc vào từng loại cỏ biển và thời gian thử nghiệm. Trong trường hợp của cỏ di trồng ở đây là cỏ Lươn chúng tôi chọn phương pháp kiểm tra sự tăng trưởng mật độ thân đứng.

Sau hơn 6 tuần di trồng, kiểm tra 3 lô thí nghiệm, mỗi lô có 10 bụi, khoảng 30\% số lượng các bụi cỏ biển bị mất do tác động cơ học của dòng chảy hoặc bị chết. Số lượng còn lại thích nghi và phát triển tốt, điều này thể hiện qua việc khảo sát mật độ trung bình thân đứng ở các lô thí nghiệm, mật độ trung bình tăng khoảng 13\%.

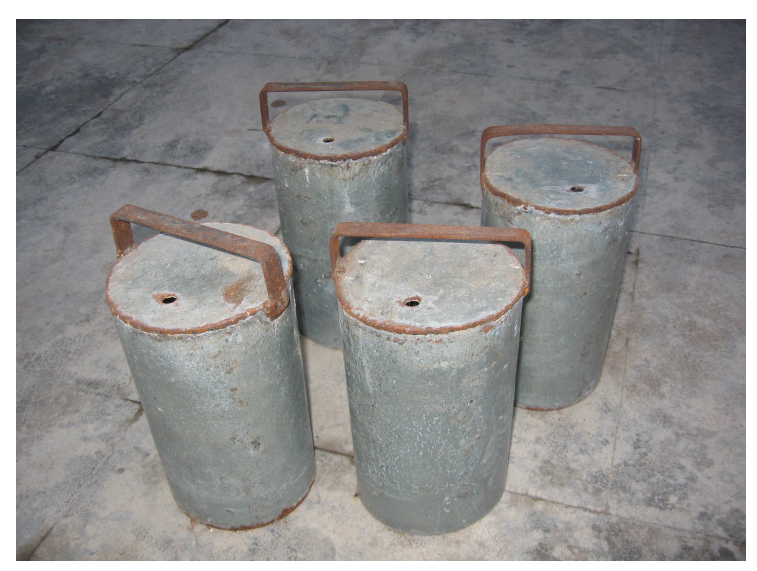

Hình 2: Dụng cụ lấy giống cỏ

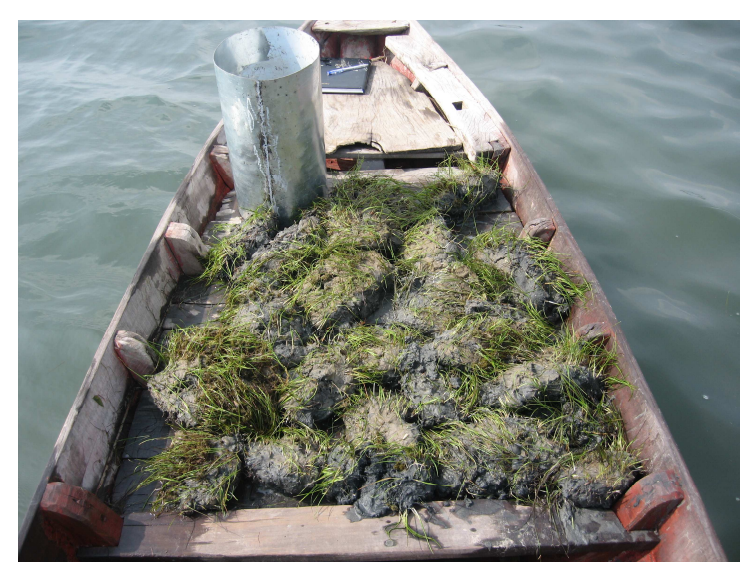

Hình 3: Vận chuyển cỏ giống đến nơi trồng

\section{Quản lý và vận hành hệ sinh thái: Giải pháp đề nghị cho vấn đề quản lý, bảo vệ và sử dụng có hiệu quả hệ sinh thái cỏ biển}

Việc phục hồi, phát triển và khai thác nguồn lợi trong các thảm cỏ biển là động lực chủ yếu trong chiến lược quản lý hệ sinh thái. Phát huy các kỹ thuật phục hồi và phát triển các nguồn lợi có giá trị kinh tế trong thảm cỏ biển như tôm, cua, ghẹ, cá. Khi được bảo vệ, nguồn giống cá Mú, cá Dìa, cua Bùn vào cư trú trong các thảm cỏ biển. Các hộ gia đình được giao nhiệm vụ bảo vệ các thảm cỏ biển có cuộc sống gắn liền với nguồn lợi mà các thảm cỏ biển mang lại cho họ.

Trong tình hình hiện nay, khi nguồn lợi các hệ sinh thái ven bờ bị suy giảm nghiêm trọng, hiệu lực của các quy định về quản lý và bảo vệ nguồn lợi còn chưa cao, thì việc xây dựng các quy định, hương ước của địa phương để bảo vệ và sử dụng hợp lý tài nguyên các thảm cỏ biển cần được đẩy mạnh. Hiện nay chưa có các thống kê đầy đủ về suy giảm đa 
dạng sinh học và các nguồn lợi có giá trị trong các hệ sinh thái ven bờ nhất là hệ sinh thái cỏ biển, nhưng có điều rõ ràng rằng một số loài có giá trị trong các thảm cỏ biển ngày nay rất hiếm gặp hay không còn nữa như cá Ngựa, ốc nhảy, Nhum sọ, Hải sâm cát...Nhiều loài tôm thuộc họ Penaeidae, cua, ghẹ, động vật thân mềm, các loài cá đặc biệt trong các thảm cỏ biển như cá Dìa, cá Đối suy giảm nhanh. Việc suy giảm này ngoài nguyên nhân do khai thác quá mức, còn nguyên nhân chính là do nơi cư trú sinh vật bị xáo trộn, cái nôi ươm nuôi sinh vật bị phá hủy.

Ý nghĩa của việc phục hồi các thảm cỏ biển là phục hồi nơi cư trú sinh vật, làm cho các sinh vật sống chung trong các thảm cỏ biển được đa dạng hơn và các đối tượng nguồn lợi có giá trị đã bị suy giảm hay mất đi nay được phục hồi lại

Lợi ích kinh tế các thảm cỏ biển gắn liền với đời sống cộng đồng ngư dân ven biển từ bao đời nay, là vùng thường xuyên xảy ra các hoạt động nuôi trồng và đánh bắt hải sản. Vì vậy việc bảo vệ và quản lý nó phải xây dựng trên cơ sở cộng đồng, được sự ủng hộ của cộng đồng với mục tiêu sử dụng có hiệu quả hệ sinh thái, duy trì, phát triển bền vững nguồn lợi và cho môi trường sạch.

Nghiên cứu mô hình phục hồi và bảo vệ nơi cư trú cỏ biển cũng như nguồn lợi sinh vật chung sống giúp cho cộng đồng hiểu rõ giá trị của hệ sinh thái cỏ biển đối với nguồn lợi sinh vật và môi trường, từ đó họ có nhận thức sâu sắc và ủng hộ nó như là cách duy nhất để bảo đảm sinh kế gia đình. Vì vùng phân bố cỏ biển chủ yếu là vùng dưới triều, các thảm cỏ biển ít bị sức ép bởi việc phát triển nuôi tôm hơn rừng ngập mặn. Vấn đề là nhận thức của cộng đồng một khi họ nhận thấy cũng như được trang bị đầy đủ các hiểu biết trong việc quản lý, phát triển sử dụng hệ sinh thái một cách hợp lý để đem lại hiệu quả thiết thực.

Vì vậy, giải pháp đề nghị cho việc phục hồi và quản lý hệ sinh thái dựa trên cơ sở cộng đồng và vì lợi ích của cộng đồng, đó là:

- Giao cho các hộ gia đình hoặc cá nhân tiên tiến, quản lý khu vực triển khai mô hình phục hồi, theo các kỹ thuật đã được chuyển giao, xác định ranh giới khu vực bảo vệ. Người dân sử dụng các diện tích này như diện tích canh tác và tuân thủ theo đúng luật pháp Nhà nước.

- Cùng với việc di trồng phục hồi và bảo vệ cỏ biển, chuyển giao kỹ thuật cho người dân nuôi phục hồi một số các đối tượng sống chung trong các thảm cỏ biển. Trước mắt, ở địa bàn xã Tam Giang, đó là các đối tượng hàu, ngao, ốc nhảy, ốc càng, cua, ghẹ, cá mú. Người dân có thể được sử dụng vùng đệm phía ngoài thảm cỏ biển để phát triển nghề nuôi. 
- Khi nguồn lợi được phục hồi, người dân sẽ được hướng dẫn cách khai thác hợp lý để duy trì bền vững. Người dân sẽ có 2 cách thu nhập : thu nhập từ nguồn lợi tự nhiên do phục hồi HST và thu nhập từ việc phát triển nuôi trồng một số đối tượng thân thiện với môi trường, thích hợp trong hệ sinh thái.

- Chính quyền địa phương cần có những quy định và thông báo rộng rãi cho các cộng đồng dân cư vùng lân cận về khu vực phục hồi bảo vệ, thực hiện nghiêm luật pháp Nhà nước cấm các hình thức đánh bắt có tính hủy diệt.

Việc thu nhập nguồn lợi từ khu vực bảo vệ phải là động lực và lợi ích hấp dẫn khiến người dân phải nổ lực gìn giữ và tôn tạo hệ sinh thái. Nếu biết khai thác hợp lý mô hình, sử dụng triệt để các cơ sở khoa học, người dân sẽ khai thác vùng bảo vệ phục hồi như nơi canh tác của họ và mô hình chắc chắn sẽ được nhân rộng nhiều địa phương khác. Khi đó tài nguyên nguồn lợi và tài nguyên môi trường của các hệ sinh thái ven bờ sẽ được phát triển, sử dụng một cách hợp lý và bền vững.

Thời gian còn quá ngắn để có thể đánh giá cụ thể sự phục hồi của nguồn lợi sinh vật trong hệ sinh thái, nhưng có điều rõ ràng rằng hàng ngày có khá nhiều ghe thuyền của ngư dân tập trung khai thác xung quanh hàng rào khu vực quản lý và nhóm hạt nhân rất vất vả trong việc bảo vệ. Cá Mú con, cá Dìa, cá Đối, tôm, cua, ghẹ là các nguồn lợi có giá trị tập trung cư trú và ẩn nấp trong khu vực quản lý hệ sinh thái cỏ biển.

\section{KẾT LUẬN}

- Thôn 1, 2 xã Tam Giang, huyện Núi Thành có diện tích 10 ha được chọn để triển khai trình diễn mô hình phục hồi hệ sinh thái cỏ biển. Đây là vùng được lựa chọn dựa theo các tiêu chí về đa dạng sinh học, được xác định có ý nghĩa quan trọng về nguồn lợi sinh vật cho vùng ven biển Núi Thành và vùng biển lân cận. Thảm cỏ biển đang bị suy giảm khoảng 30\%, nguyên nhân chính do các hoạt động khai thác hải sản có tính hủy diệt.

- Nhóm hạt nhân thực hiện mô hình trình diễn gồm 4 người, có nhóm trưởng, do chính quyền địa phương và các đoàn thể giới thiệu. Phó Chủ tịch UBND xã Tam Giang được phân công theo dõi, giám sát và đôn đốc hoạt động của nhóm.

- Loài cỏ biển đã được chọn để di trồng phục hồi là cỏ Lươn. Đây là các loài ưu thế bản địa. Các thử nghiệm cho thấy chúng có khả năng di trồng và phát triển tốt, sau 6 tuần di trồng, mật độ thân đứng có thể tăng đến 13\%.

- Việc vận hành mô hình được đề nghị trên cơ sở gắn kết lợi ích khai thác hợp lý và bền vững nguồn lợi trong hệ sinh thái cỏ biển với việc quản lý và bảo vệ chúng. 
Lòi cám ơn: Tác giả chân thành cám ơn Tổng cục Bảo vệ Môi trường, Bộ Tài Nguyên \& Môi trường đã tài trợ kinh phí và PGS TSKH Nguyễn Tác An, chủ dự án đã tạo điều kiện cho việc thực hiện mô hình, ThS Nguyễn Xuân Vỵ, phòng Thực vật biển, Viện Hải dương học, hỗ trợ công tác khảo sát và nhóm hạt nhân ở xã Tam Giang, Núi Thành gồm 4 người do ông Đinh Viện làm nhóm trưởng đã tổ chức quản lý và di trồng cỏ biển.

\section{TÀI LIỆU THAM KHẢO}

1. Davis, R. C. and Federick T. Short, 1997. Restoring eelgrass Zostera marina L. habitat using a new transplanting technique: the horizontal rhizomeMethod. Aquatic Botany 59: 1-15.

2. English, S.,Wilkinson, C. and V. Baker, 1994. Survey Manual for Tropical Marine Resources. Chapter 5: Seagrass Communities pp. 235-264.

3. Huỳnh Quang Năng và Nguyễn Hũu Đại, 1981. Quy phạm Nhà nước. Quy phạm tạm thời điều tra tổng hợp biển. Quy phạm điều tra rong biển. QPVN 17-79, tr. 1-43. Ủy Ban Khoa học và Kỹ Thuật Nhà nước Hà Nội ấn hành.

4. Nguyễn Hũu Đại, Nguyễn Xuân Hòa, Phạm Hũu Trí và Nguyễn thị Lĩnh, 1999. Các thảm cỏ biển phía Nam Việt Nam. Tuyển tập Báo cáo Khoa học Hội nghị toàn Quốc lần thứ 4 về Khoa học và công nghệ biển. Hà Nội 12-13/11/1999. Tập 2 : 967974. NXB Thống kê, Hà Nội.

5. Nguyen Huu Dai, Nguyen Xuan Hoa, Pham Huu Tri and Nguyen Thi Linh, 2000. Seagrass beds along the southern coast of Vietnam and their significance for associated flora and fauna. Collection of Marine Research Works. Vol. 10: 149-160. Science and Technique Publishing House. Ho Chi Minh City.

6. Nguyễn Hữu Đại, Phạm Hữu Trí, Nguyễn Thị Lĩnh, Nguyễn Xuân Vy, 2004. Sự suy giảm các thảm cỏ biển ở Khánh Hòa và khả năng phục hồi chúng. Tuyển tập báo cáo Khoa học Hội nghị Khoa học Biển Đông 2002. tr. 359-368. Nha Trang , 1619/9/2002. NXB Nông Nghiệp

7. Nguyễn Hữu Đại, 2005. Phục hồi và bảo vệ các thảm cỏ biển - Mô hình quản lý và phát triển bền vững vùng biển ven bờ. Kỷ yếu Hội thảo toàn Quốc Bảo vệ môi trường và Nguồn lợi thủy sản. Hải Phòng 14-15/01/2005. Tr. 388-395. NXB Nông nghiệp Hà Nội.

8. Philips, R. C. and C. P. McRoy, 1990. Seagrass Research Methods. Monograph on Oceanographic Methodology. Unesco, Paris.210 pp.Unesco, Paris. 210 pp. 
9. Saito, Y. and Atobe, S., 1970. Phytosociological study of intertidal marine algae. I. Usujiri Benten-Jima, Hokkaido. Bulletin of the Faculty of Fisheries, Hokkaido University, 21: 37-69.

10. Spurgeon, J., 1998. The Socio-Economic Cost and Benefits of Coastal Habitat Rehabilitation and Creation. Marine Pollution Bulletin 37(8-12): 373-382.

\title{
MANAGEMENT AND RESTORATION OF SEAGRASS BEDS IN NUI THANH DISTRICT, QUANG NAM PROVINCE
}

\author{
NGUYEN HUU DAI
}

\begin{abstract}
Nui Thanh district, Quang Nam province have been chosen and signed by People Committee of Quang Nam province, No 938/QĐUBND in July 9/2008, and given to the Project "Integrated Management of Coastal Zone Quang Nam province" for management and restoration of seagrass ecosystem. This area is an important distribution area of seagrass in An Hoa lagoon, Nui Thanh district. Zostera japonica is dominant species, the cover can reach 25-50\%. Unfortunately, these beds are quickly reduced by several destructive fishing gear and methods. A model of management and restoration of seagrass beds has been carried out with the help of local government, four workers in seagrass group and local people. Zostera japonica had been transplanted by planting unit method. Preliminary result showed that after 6 weeks of planting, the density increased 13\%. A proposed solution for management seagrass beds is based on close connection between the benefit from the reasonable and sustainable exploitation of the resources in seagrass ecosystem and their management.
\end{abstract}

Ngày nhận bài: 16 - 7 - 2009

Ngưòi nhận xét: PGS. TS. Nguyễn Hữu Phụng 